\title{
Universiteit
}

Leiden

The Netherlands

\section{Verb copying in Mandarin Chinese}

Cheng, L.L.; Corver, N.; Nunes, J.

\section{Citation}

Cheng, L. L. (2007). Verb copying in Mandarin Chinese. In N. Corver \& J. Nunes (Eds.), Linguistik Aktuell/Linguistics Today (pp. 151-174). Amsterdam: John Benjamins Publishers. doi:10.1075/la.107.07che

Version:

Publisher's Version

License:

Licensed under Article 25fa Copyright Act/Law (Amendment Taverne)

Downloaded from: $\quad$ https://hdl.handle.net/1887/3247509

Note: To cite this publication please use the final published version (if applicable). 


\section{The Copy Theory of Movement}

Edited by

Norbert Corver

Utrecht University

Jairo Nunes

University of São Paulo

John Benjamins Publishing Company

Amsterdam/Philadelphia 


\title{
Verb copying in Mandarin Chinese
}

\author{
Lisa Lai-Shen Cheng \\ Leiden University
}

This chapter examines the ambiguity in resultative constructions with verb copying in Mandarin Chinese (resultative de-clauses and resultative compounds) and argues that the ambiguity is the result of two different derivations, which have in common the fact that more than one copy of the verb is phonetically realized. It is argued that both standard movement and sideward movement (in the sense of Nunes 2001, 2004) are used for verb copying in resultative de-clauses, leading to different interpretations. In the case of standard movement, the subject of the resultative clause is raised to the matrix clause, accompanied by verb movement, yielding an object-result reading. In the case of subject-result reading, ergativity shift is involved and the subject of the resultative clause becomes the subject of the matrix clause. In the latter case, the verb is copied to accommodate a thematic noun phrase associated with a verb (via sideward movement). For both readings, due to a modified structure in the lower copy, both copies are allowed to be pronounced, without violating the LCA. Using data from verb copying in resultatives, the chapter further examines how copying is restricted to avoid unwanted copying, lending independent support to Hornstein and Nunes' (2002) proposal that the copy operation may be triggered by $\theta$-requirements.

\section{Introduction}

Nunes (2004) and Bošković and Nunes (this volume) argue that many of the phenomena of copying can be explained by an analysis based on the phonetic realization of traces, assuming the (revised) copy theory of movement (See Nunes 2004). In this paper, 1 examine the phenomenon of verb copying in Mandarin Chinese within the copy theory of movement. In particular, I investigate the ambiguity in

* I thank the audience in the lectures in Beijing University, LSA summer school, the European Chinese Linguistics Spring School, as well as the audience in the Copying Workshop in Utrecht and the Resultative Workshop in Leiden (June 2005) for comments and suggestions. In addition, I thank the three reviewers as well as Norbert Corver and Jairo Nunes for detailed comments and suggestions. 
verb copying in resultative constructions (resultative clauses and resultative compounds) and argue that the ambiguity is the result of two different movement operations. I further show that in both cases, the spelling out of multiple copies is due to the phonetic realization of "traces."

Using data from verb copying in resultatives, I examine further how copying is restricted to avoid unwanted copying. In particular, I support the Last Resort view of copying (Hornstein and Nunes 2002), which restricts copying to cases where formal feature checking requirements need to be satisfied. In addition, I argue that the analysis of verb copying involving various complemental and adverbial expressions sheds light on how these expressions are merged in the structure.

This paper is organized as follows. I first present the phenomenon of verb copying in Section 2. In Section 3, I examine verb copying in resultative de-clauses in detail. I argue that both standard movement and Sideward Movement are used for verb copying in resultative de-clauses, leading to different interpretations. In Section 4, I discuss the triggering of copying in the case of Sideward Movement, as well as the ergativity shift that we encounter. In Section 5, I show that the present analysis carries over to explain verb copying with durative/frequency expressions, manner $d e$-clauses, and resultative compounds. In addition, I discuss data from Jieyang Chao-Zhou dialect in support of the ergativity shift we find in data with resultatives. A brief conclusion is presented in Section 6 .

\section{The verb copying construction ${ }^{1}$}

An often cited case of verb copying concerns durative/frequency expressions, as shown by the data in (1). The verb $c h i \bar{t}$ 'eat' can be followed by either a nominal complement ( fàn 'rice' in (1b)) or an adverbial phrase such as liäng ge xiăoshi 'two hours' (1b). However, having both follow the verb, as in (1c), yields an ungrammatical sentence. ${ }^{2}$

(1) Durative/frequency expressions

a. tà chī-le liăng ge xiăoshí

he eat-PERF two CL hour

'He ate for two hours.'

1. A-not-A questions (a type of yes-no question) are not discussed here, because they involve a different type verb copying. Verb copying involving simple reduplication of verbs (with no noun phrase in between) is not discussed here either.

2. As discussed in the literature, there are examples in which a verb can be followed by two constituents. These are discussed in Section 5.1. 


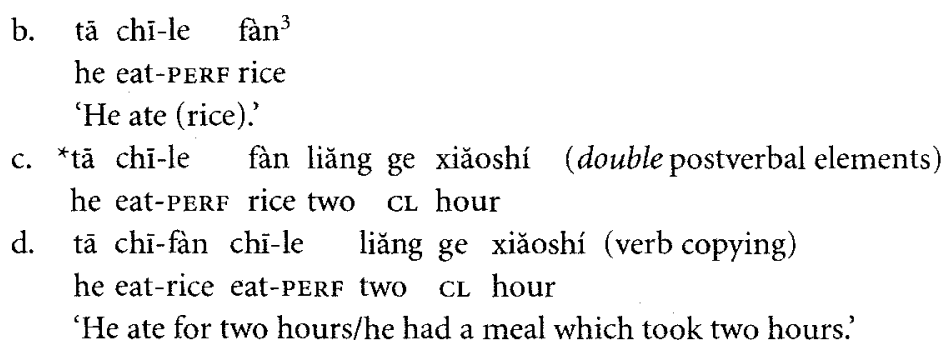

Verb copying can void the ungrammaticality in (1c), as shown in (1d). This led Huang $(1982,1984)$ to propose the Phrase Structure Constraint for Chinese in (2), which rules out double postverbal constituents.

(2) Phrase structure constraint (PSC) (Huang, 1984)

Within a given sentence in Chinese, the head (the verb or VP) may branch to the left only once, and only on the lowest level of expansion.

The PSC allows for the VP in Chinese to have the branching in (3a), but not in (3b) since the latter VP branches to the left twice (both at the VP level and at the $\mathrm{V}^{\prime}$ level).

(3)

a.

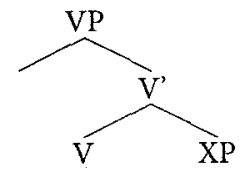

b.

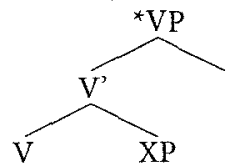

We can thus understand the unacceptability of (1c) as being a violation of the PSC. Under this view, the verb copying strategy is used in order to avoid the violation. Other examples of verb copying are illustrated in (4) and (5). ${ }^{4}$

(4) Resultative de-clauses
a. *tā qí mă de hĕn lèi he ride horse DE very tired
b. tā qí mă qí de hěn lèi he ride horse ride DE very tired 'He got tired riding (a horse).
c. tā qí de mă hĕn lèi he ride $\mathrm{DE}$ horse very tired 'He rode the horse and as a result the horse is tired.'

3. This sentence also has an activity reading. The object noun phrase can thus be considered to be an "inherent" or "dummy" object (see Cheng and Sybesma 1998 as well as discussion in Section 5.3.2).

4. The de of resultative de-clauses is on the surface similar to the one in manner de-clauses, but they are in fact not the same. See Section 5.2 for a brief discussion. 
(5) Manner de-clauses

a. *tã kàn zhè-bĕn xiăoshuō de hěn kuài he read thišci ${ }^{*}$ novel. DE very fast 'He read this novel very fast.'

b. tã kàn zhè-bĕn xiăoshuō kàn de hĕn kuài he read this-CL novel read $D E$ very fast

The examples in (4) and (5) illustrate a pattern similar to the durative/frequency expressions. However, the view that verb copying is a rescue strategy runs into difficulty with the data in (6) and (7):

(6) a. wŏ děng-le Zhāngsān bàntiān

(D/F expressions)

I wait-perf Zhangsan half-day

b. wǒ děng Zhāngsān dēng-le bàntiān

I wait Zhangsan wait-perf half-day

'I have waited for Zhangsan for a long time.'

(7) a. tā qí-lèi-le (nèi-pī) mă $\quad$ (Resultative compounds)

he ride-tired-PERF that-CL horse

'He rode the horse and the horse became tired.'

$\rightarrow$ other readings possible (see also Cheng 1997 and Li 1999 among others)

b. tã qí (nèi-pī) mă qí-lèi-le

he ride that-CL horse ride-tired-perF

'He rode and got tired.' (Not: the horse is tired)

In (6a), the definite object Zhāngsān can follow the verb, together with the durative expression bàntiān 'half-day' (apparently violating the PSC); and in (7a), it is clear that (nèi-pi) mă '(that) horse' is the sole complement of the resultative verb compound. In neither case is verb copying obligatory.

Below, I will first focus on the resultative de-clauses, which can shed light on the mechanism of verb copying. The other cases will be discussed in Section $5 .^{5}$

\section{Resultative de-clauses}

Resultative de-clauses provide a good case to investigate verb copying, since they allow.quite a range of flexibility.

\subsection{The structure}

Consider first the basic structure of resultative de-clauses.

5. Verb copying examples with locative and directional phrases can be directly captured under the same analysis if we treat locative and directional phrases on a par with resultatives (cf. Sybesma 1999). 
(8) a. tā kū de wŏ dōu fán le he cry DE I even annoyed LE 'He cried to the extent that I got annoyed.'

b. tā qi de (nèi-pĩ) mă hĕn lèi he ride $\mathrm{DE}$ that-CL horse very tired 'He rode the horse and as a result the horse is tired.'

Sentences such as $(8 \mathrm{a}, \mathrm{b})$ show that the clause following de can be a full clause. Temporal adverbs as well as aspectual markers can also appear within the de-clause. Sybesma (1999) treats de as the head of an Extent Phrase (ExtP/deP). A sentence such as ( $8 \mathrm{a})$ can thus be interpreted as: 'he caused a crying event to the extent that I got annoyed'.

Following Sybesma (1999), I assume that the basic VP structure of (8b) is (9):

(9) $\left[_{V P}\right.$ ride $\left[_{D E P}\right.$ de [ horse tired] $\left.]\right]$

We have seen that verb copying is possible with resultative de-clauses. Consider now the examples in (10).

(10) a. tā qí nèi-pī mă qí de hĕn lèi he ride that-CL horse ride $\mathrm{DE}$ very tired

(i) 'He rode the horse and the horse got very tired.' (object-result)

(ii) 'He rode the horse and became tired as a result.' (subject-result)

b. tā dă Ľsì dă de hěn căn

he hit Lisi hit DE very miserable

'He hit Lisi to the extent that Lisi became very miserable.'

(10a) is particularly interesting because it allows two readings. ${ }^{6}$ In the reading in $(10 \mathrm{a}-\mathrm{i})$, nè $i-p \bar{\imath} m a ̆$ ' the horse' is interpreted as the one being linked to the resultative predicate hĕn lèi 'very tired' while in the second reading $(10 \mathrm{a}-\mathrm{ii})$, $t \vec{a}$ 'he' is the one being linked to the resultative predicate. I'll call the first reading the "objectresult" reading since the result is connected to the logical object of the matrix verb and the second reading the "subject-result" reading as the resultative predicate is predicated of the logical subject of the matrix verb.

For both readings, it should be noted that there is no overt noun phrase in the de-clause. The subject of the resultative clause is phonetically not spelled-out.

Sentences which yield "object-result" reading are interchangeable with băsentences. Consider the $b \breve{a}$-counterparts of $(10 a, b)$ :
a. tā bă nèi-pī mă qí de hĕn lèi
he $B A$ that-CL horse ride $D E$ very tired
'He rode the horse and the horse got very tired.'

6. (10b) is in principle also ambiguous, but the "subject-result" reading is a bit incompatible with our knowledge of the world. That is, we don't expect that hitting someone would yield a result such that the hitter becomes miserable. 
b. tā bă Ľsì dă de hĕn căn

he BA Lisi hit DE very miserable

'He hit Lisì to the extent that Lisi became very miserable.'

Note that the bă-counterparts shown in $(11 \mathrm{a}, \mathrm{b})$ only have an object-result reading. I assume, following Sybesma (1999), that bă is the head of the small (causative) v. Furthermore, the noun phrase following $b a$ is moved from the subject position of the resultative de-clause (as in (12)). ${ }^{7}$ Considering that in the object result-reading of the verb copying cases, the verb can be replaced by ba (and they cannot cooccur), the null hypothesis for verb copying sentences is that the copied verb also occupies $v$, as shown in (12b):

(12)

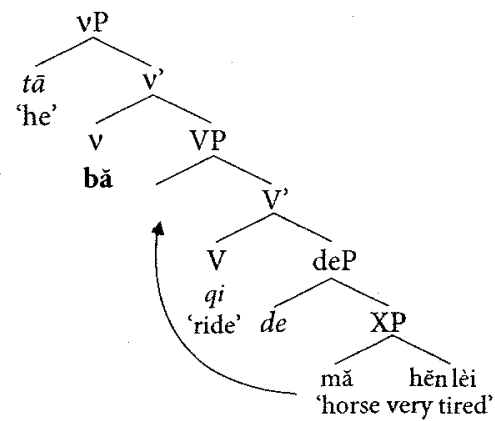

b.

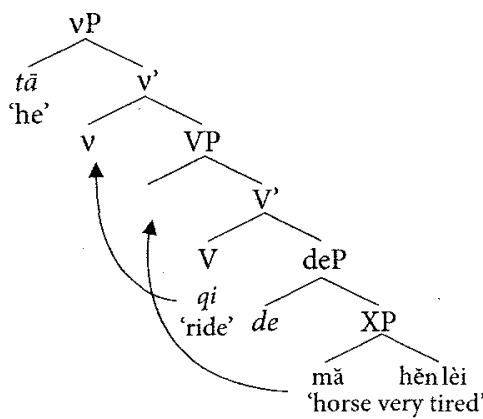

In the derivations in $(12 a, b)$, the noun phrase mă 'horse' raises from within the $d e \mathrm{P}$ to the matrix SpecVP. In the case of verb copying, I assume that the copying is a result of movement (the mechanism of verb copying will be discussed in Section 3.2). We have seen that verb copying (object-result reading) and bă go handin-hand.

However, when the matrix verb is intransitive, though a $b \breve{a}$-variant is allowed, verb copying is not possible, as $(13 b, c)$ show:
a. tā kū de shŏupà hèn shī
he cry $D E$ handkerchief very wet
b. tā bă shŏupà kū de hĕn shī
he BA handkerchief cry $\mathrm{DE}$ very wet
c. ${ }^{*}$ tã kū shŏupà $k \bar{u}$ de hĕn shì
he cry handkerchief cry DE very wet

'He cried to the extent that the handkerchief got wet.'

7. In this paper, as will be discussed in more detail in Section $4, \mathrm{I}$ assume that the movement (i.e., Copy and Merge) of the noun phrase in the resultative de-clause is related to thetarequirements. 
This shows that $b \breve{a}$-constructions are not equivalent to verb-copying (objectresult) cases. If the derivations in (12a,b) are on the right track, the ungrammaticality of (13c) is probably related to the fact that the verb cannot move up or that the SpecVP cannot accommodate the noun phrase. We will discuss this in Section 4.

\subsection{Verb copying - 1st strategy}

I assume the basic framework of movement and realiziation of multiple copies in Nunes (2004) (see also Bošković and Nunes (this volume)). Chain reduction (i.e., deletion of constituents of a non-trivial chain) takes place in order to yield a linearizable sequence according to the L(inear) C(orrespondence) $\mathrm{A}(\mathrm{xiom})$ (Kayne, 1994). When chain reduction fails to apply, it is due to modification of word structure (e.g., fusion, as in Distributed Morphology (see Halle and Marantz 1993)).

We have indicated that when verb copying is comparable to bă-sentences (i.e., "object-result" reading), there is movement of the noun phrase from the resultative $d e$-clause. Further, we assume that the copied verb can occupy the small $v$, just like $b a ̆$. Instead of base-generating $b \breve{a}$, the verb is copied and then merged to $v$. The question that arises is why both copies can be realized. ${ }^{8}$

I propose that after the verb raises (i.e., copies and merges) to $v$, in the morphological component, the lower copy of the verb is fused with de (under adjacency; see also Bobaljik 1995). ${ }^{9}$ Due to fusion (which merges the morphological structure of the verb and de), LCA cannot see the inner elements in [ $\mathrm{v}$ V-de] (i.e., treating $\mathrm{V}$ and $\left[_{v} \mathrm{~V}\right.$-de] as distinct). Chain reduction will thus not apply. Both copies are thus allowed to be phonologically realized.

Verb copying in this case is thus the result of standard movement (Copy + Merge) and lack of chain reduction.

\subsection{Verb copying - 2nd strategy}

The first strategy of verb copying, i.e., standard movement-related copying, takes care of the "object-result" reading of resultative de-clauses. Consider now the "subject-result" reading.

The "object-result" reading arises due to the fact that the noun phrase starts out as the subject of the resultative de-clause and it raises to the SpecVP position in the matrix. For the "subject-result" readings, the null hypothesis should be that the

8. Due to the limit of space, I cannot do any justice in discussing previous proposals (e.g., Paul 2002 and Gouguet 2004 among others). The analysis offered in this paper, I think, covers a wider range of cases than these proposals.

9. De always carries neutral tone, suggesting that it is like a clitic/suffixal element (similar to the perfective marker $-l e$, and the dimunitive suffix $-z i$.) 
subject noun phrase in the matrix is the same as the noun phrase in the resultative de-clause. Hoekstra and Mulder 1990 argue that there is ergativity shift in case of resultatives. That is, à non-ergative verb can become ergative if a resultative clause is added. ${ }^{10}$ In the case of Chinese resultative de-clauses, this is not at all surprising, as we can see from the examples in (14).
a. tà qí de hěn lèi
he ride $\mathrm{DE}$ very tired
'He rode and got tired.'
b. shǒupà kū de hèn shī
handkerchief cry DE very wet
'The handkerchief is wet as a result of crying.'
c. qúu-xié tì de hěn pò
ball-shoes kick DE very broken
'The sport shoes are broken as a result of kicking/playing soccer.'

In all the cases in (14), only one single argument noun phrase is present, and this noun phrase is also interpreted as the subject of the resultative clause. In (14a), the verb qi' 'ride' is not used transitively (i.e., it becomes a one-argument verb). In (14b), the agent (and the only) argument of the verb is suppressed. In (14c), neither the agent nor the theme argument of the verb is present. These examples show a shift to an ergative structure when the resultative de-clause is added. In other words, we have an ergative sentence comparable to the one in (15a), which has a causative counterpart in (15b):

(15) a. The ship sank.

b. They sank the ship.

Following Sybesma (1999), I assume that the single noun phrase in the sentences in $(14 \mathrm{a}-\mathrm{c})$ is first merged in the resultative de-clause (as proposed in Hoekstra and Mulder 1990, and raised to the matrix (similar to standard cases of ergative verbs in which the single argument starts out as an internal argument; in this case, internal means inside the resultative clause).

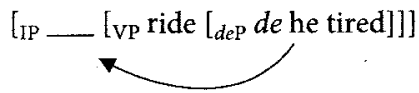

There is no vP layer, nor is SpecVP available to host any object-like argument (see more details in Section 4$).{ }^{11}$

10. More specifically, they argue that in cases where a verb is shifted to an ergative verb, it has a structure in which the single argument is generated inside the small clause complement (similar to a copular structure) and there is no position in the VP for this argument.

11. As mentioned above, $\mathrm{I}$ am assuming that $\mathrm{vP}$ is actually not present. However, it is possible to add a vP (causative layer) to generate a sentence such as (i) (similar to (15b)): 
Further, $(14 a-c)$ show clearly that the noun phrase in the resultative predicate, which may not be thematically related to the matrix verb, can raise to the matrix. This is similar to the ship in (15a) raising from its base (i.e., object) position to the matrix position when the verb is used ergatively (and non-causatively).

Consider now more cases with a "subject-result" reading:
a. tā qí mă qí de hĕn lèi
he ride horse ride DE very tired
'He rode and got tired.'
b. tã kàn shũ kàn de hĕn lèi he read book read DE very tired 'He read and got tired.'
c. tā chī fàn chī de hěn băo he eat rice eat DE very full 'He ate and became very full.'

The sentences in $(17 \mathrm{a}-\mathrm{c})$ do not have an "object-result" reading at all. All of these sentences involve a bare noun as the object of the first verb, and the V-O combination yields an activity reading (or necessarily has a non-specific indefinite reading). ${ }^{12}$ Huang $(1982,1992)$ suggests that the V-O combination is actually an adjunct.

I have suggested earlier that when we have the "subject-result" reading, the noun phrase which is first merged in the de-clause subsequently raises up to the matrix subject position (if there is no causer (see Footnote 11)). Given that there is no SpecVP (see Section 4), the object noun phrase associated with the verb copy cannot be generated in SpecVP. I propose that the V-O combination is generated via Sideward Movement (see Nunes 2001, 2004 among others).

The intuition behind Sideward Movement is that once Move is decomposed as Copy and Merge, nothing in the system can or should stipulate that the copy should be merged to the structure where the original item comes from. If the copy is merged with another syntactic object being built, we get a configuration which Nunes calls Sideward Movement, as illustrated in (18).
a. $\quad{ }_{\mathrm{K}} \ldots \alpha_{\text {Copy }}^{\left.\alpha^{\mathrm{i}} \ldots\right]} \alpha_{4}^{\mathrm{i}}$

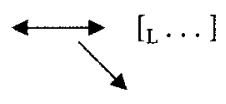
(Nunes 2004, p. 90)
b. $\quad\left[K \ldots \alpha^{\mathrm{i}} \ldots\right]$
$\left[{ }_{M} \alpha^{i}[L]\right.$

(i) nèi-pī mă qí de wŏ hĕn lèi that-CL horse ride DE I very tired

'That horse made me very tired by my riding it.'

12. It is not the case that the subject reading is necessarily related to a non-specific indefinite object noun phrase. (10a) shows that given a definite object noun phrase, ambiguity still arises, i.e., "subject-result" reading is still possible. 
In (18a), $a$ is copied. And there is another structure $L$ being built along the side. As illustrated in (18b), instead of merging directly to $K$, $a$ is merged with $L$, forming $M$.

In the case of the "subject-result" reading, there is no position available for the object noun phrase (due to the ergative structure). After the verb is copied, instead of merging to the original structure, it merges with the object noun phrase, which has been constructed separately, projecting a VP, as illustrated in (19):

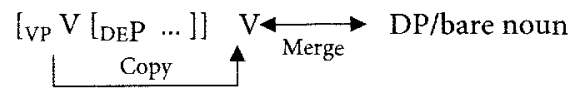

The VP formed after the Sideward Movement can subsequently merge to the original structure, by adjoining to the VP. This yields the same structure which Huang (1982, 1992) suggests:

(20) tā ${ }_{i}\left[l_{V P 1} q i\right.$ mă] [VP2 qí de $t_{i}$ hĕn lèi $\left.]\right]$ he ridehorse ride $\mathrm{DE}$ very tired

In the structure in (20), qí-de is also fused in morphology as a morphological unit. As a result, chain reduction is also not triggered in such a case, and realization of both copies is thus possible.

It should be noted that the structure in (20) treats qí-mă 'ride-horse' as a constituent, which is supported by the fact that this sequence can be fronted as a unit:

(21) qí mă, tā qí de hĕn lèi ride horse he ride DE very tired

'Riding a horse, he got very tired.'

More importantly, recall that verb copying involving a definite object can yield both a subject-result and an object-result reading (as in (10a), repeated here as (22a)). However, if the verb-object sequence is fronted, only one reading, in particular, the subject-result reading remains, as shown in (22b): ${ }^{13}$

a. tā qí nèi-pī mă qí de hĕn lèi he ride that $-\mathrm{CL}$ horse ride $\mathrm{DE}$ very tired

(i) 'He rode the horse and the horse got very tired.'

(ii) 'He rode the horse and became tired as a result.'

13. I assume here that movement is involved, instead of simply adjoining the VP to the matrix, because island effects can be detected, as indicated by (i) and (ii), with complex NP island and adjunct island, respectively.

(i) ?*qí nèi-pi mă, wŏ jùjué-le Guōjing qí de hěn lèi de shuōfă ride that-CL horse I reject-PERF Guojing ride $\mathrm{DE}$ very tired $\mathrm{DE}$ claim 'As for riding that horse, I rejected the claim that Guojing got tired.' 
b. qí nèi-pì mă tā qí de hĕn lèi ride that-CL horse he ride DE very tired 'Riding that horse, he got very tired.' (= "subject-result") Not: 'Riding that horse, he got the horse tired.'

This follows naturally from the proposal put forth here: in the second strategy of verb copying, Sideward Movement is involved, yielding a VP consisting of the verb-object sequence. Since the $\mathrm{V}-\mathrm{O}$ sequence forms a constituent, it can be fronted as a unit. On the other hand, the object-result reading is derived by standard movement of the verb from $V$ to $v$, and by the movement of the noun phrase from $d e \mathrm{P}$ to SpecVP. The verb and the noun phrase in question crucially do not form a constituent, and thus cannot move as a unit.

\section{Triggering copy, sideward movement, and optionality of SpecVP}

We have seen two copying strategies, each yielding a different interpretation. The "standard" movement gives us the "object-result" reading while Sideward Movement gives us the "subject-result" reading. In both cases, we see an asymmetry concerning transitive and intranstive verbs. In particular, (13b) (repeated below as (23)) should not be allowed regardless of which copying strategy is used.

(23) * tā kū shŏupà kū de hĕn shī he cry handkerchief cry DE very wet

With respect to the first strategy, what needs to be blocked is the movement of shoupà 'handkerchief' from the de-clause to the matrix SpecVP.

And for the second strategy, consider the sentence in (24), which intends to have (and supposes to be biased towards) a "subject-result" reading.

(24) * tā kū shŏupà kū de hĕn lèi

he cry handkerchief cry DE very tired

Intended: "He is tired from having cried (on) the handkerchief.'

To derive (24), the verb $k \bar{u}$ 'cry' has to copy, and sideward move to the object noun phrase shŏupà 'handkerchief', which is being built separately (while the subject noun phrase is moved from the de-clause).

From these ungrammatical examples, it is clear that both the copying of the noun phrase (in the first strategy) and the copying of the verb (in the second strategy) have to be restricted.

(ii) ?*kàn shū, women [zai měi-ge rén dōu kàn de hěn lèi zhīhòu] cái jiànmiàn read book we at every-CL person Dou read DE very tired after then meet 'As for reading, we met after everyone got tired after reading.' 
Hornstein and Nunes (2002) propose that Last Resort is a condition on the operation of Copy, with Last Resort being satisfied by formal feature checking including theta-role assignment/checking. The data with resultative verb copying in Mandarin provides further support for this.

As noted, for both strategies, there is an asymmetry between transitive and intranstive verbs. This is linked to the argument structure/theta-marking asymmetry. Consider the first stategy ("object-result" reading), and the Example (10b) (repeated here as (25)):

(25) tā dă Lùsì dă de hĕn căn he hit Lisi hit DE very miserable

'He hit Lisi to the extent that Lisi became very miserable.'

The noun phrase $L \grave{i} s i$ is first merged in the de-clause. The matrix verb dă 'hit' still needs to check its theta-feature (for its internal argument). By making a copy of Lisi and merging it to SpecVP, the theta-feature of the verb can be checked (cf. Hornstein 1999). In contrast, with an intransitive verb such as kü 'cry' (as in (23)), there is no theta-feature for the verb to check. The copying of the noun phrase shoupa 'handkerchief' in (23) will not be triggered (and thus no "raising" of the noun phrase, nor raising of the verb).

Consider now the second strategy. For a sentence such as (17b) (repeated below as (26)), the subject noun phrase is merged in the de-clause and subsequently moved to the matrix. The structure is an ergative structure and thus, the object noun phrase cannot be merged directly to SpecVP (see Section 4 below). Last Resort can trigger verb copying, merging the verb with the noun phrase shü 'book', and this VP is subsequently adjoined to the main clause VP, deriving the sentence in (26).

(26) tā kàn shū kàn de hĕn lèi he read book read DE very tired 'He read and got tired.'

Now consider (24) again. In this case, we are dealing with the verb $k \bar{u}^{\prime}$ 'cry', which has no internal theta-feature to check. Copying is thus not triggered, and therefore the derivation of sentences like (24) is blocked as well. For both strategies, Last Resort clearly restricts the copying. In the first case, the copying of a noun phrase, and in the second case, the copying of a verb. Sideward movement is thus shown to be as constrained as the standard movement.

The triggering of the verb copying operation in the case of Sideward Movement is dependent on the fact that the object noun phrase of the verb cannot be merged in the structure already established. I suggested that this is due to the fact that resultatives can trigger an ergative shift in the structure of the VP (assuming Hoekstra and Mulder 1990). However, in the above analysis of the "object-result" 
reading, I have assumed that the noun phrase in the deP moves to the SpecVP in the matrix, allowing therefore an "extra" position in the matrix, i.e., the SpecVP position. If this position were available in the cases of "subject-result" reading, we could never derive the sentences in (17). Consider the following derivation:

(27) a. $\left[{ }_{V}\right.$, ride $\left[_{D E P} d e\right.$ he very tired $\left.]\right]$

b. $\quad\left[\mathrm{VP}\right.$ horse $\left[\left[_{\mathrm{V}}\right.\right.$, ride $\left[_{\mathrm{DEP}} d e\right.$ he very tired $\left.\left.]\right]\right]$

c. $\left[_{\mathrm{IP}} \ldots\left[_{\mathrm{VP}}\right.\right.$ horse $\left[{ }_{\mathrm{V}}\right.$ ride $\left[_{\mathrm{DEP}}\right.$ de he very tired $\left.\left.\left.]\right]\right]\right]$

d. nèi-pī mă qì de tā hěn lèi that-CL horse ride $\mathrm{DE}$ he very tired 'That horse made him tired by his riding it.'

In (27a), he is the subject of the predicate in the deP. The matrix verb ride still has one theta-role to check (i.e., the theme/object role). If we allow the SpecVP to be projected, and merge horse in that position, we will get a representation such as (27b). Consider now (27c). The noun phrase that can move up to SpecIP should be horse since it is a hierarchically higher than he. The sentence generated by this derivation is not an ungrammatical sentence (cf. (27d)), but it has a different reading, with horse as the causer (see Foonote 11). However, crucially, the sentence in (10a) (with the "subject-result" reading) cannot be generated along these lines, as $t \bar{a}$ 'he' needs to be in the matrix position.

This entails that ergativity shift of the matrix verb is optional with resultative de-clauses. (27d) is derived if there is indeed ergativity shift and a causative layer is added (i.e., horse is then the causer). The question that remains concerns sentences such as (4c) (repeated as (28)). This is an object-result reading case without verb copying. ${ }^{14}$

(28) tā qì de mă hĕn lèi he ride DE horse very tired 'He rode the horse and as a result the horse is tired.'

We can treat (28): on a par with (27d). That is, there is indeed ergativity shift (and there is one single argument left, which is generated inside the resultative clause). The matrix argument is a causer argument: he caused a riding event such that the horse got tired as a result.

In Section 5.3, I provide data from Jieyang Chao-Zhou dialect for further support for the optionality of ergativity with resultative $d e$-clauses.

14. Both (27d) and (28) do not involve verb copying. The causer argument is added to the structure without triggering syntactic copying of the verb. This is compatible with Hornstein and Nunes (2002) proposal regarding the last resort nature of Copy. This also entails that the verb does not raise to the causative layer in Chinese. 


\section{Other verb copying cases}

We discussed in the Introduction instances of verb copying in addition to the Resultative constructions. In this section, we examine each case with respect to the two copying strategies proposed above.

\section{1 $\mathrm{D}$ (uration)/F(requency) expressions}

As has been discussed in the literature, the definiteness of the direct object plays a role in the obligatoriness of copying in sentences with D/F expressions. (29a,b) provide examples of a definite object noun phrase with duration/frequency expressions and (30) examples with an indefinite object.
a. tā kàn-le nèi-běn shū sān cì
he read-PERF that-CL book three times
'He read that book three times.'

b. tā kàn nèi-běn shū kàn-le sān cì

he read that-CL book read-PERF three times

c. tā bă nèi-běn shū kàn-le sān cì

he BA that-CL book read-perf three times
a. *tā kàn-le shū sān-ge xiăoshí
he read-perf book three-CL hour
b. tā kàn shū kàn-le sān-ge xiăoshí
he read book read-perf three-cL hour
'He read for three hours.'

As the data show, with a definite object noun phrase, verb copying is optional (i.e., both (29a) and (29b) are acceptable). This verb copying sentence seems to be equivalent to the $b \breve{a}$-variant in (29c). On the other hand, with an indefinite object, verb copying is necessary, as indicated by the contrast between (30a) and (30b).

The verb copying strategies proposed in Sections 3.2 and 3.3 involve extra morphological material which is fused with the verb. This creates a modified morphological structure which allows the copies to escape from Chain Reduction. One might conclude from this and from the data in (29) that le 'perfective marker' constitutes this extra material in (29b) and (30b). However, this is not the case, as the sentences in (31) show: here le is not present, and yet we find copying.

\footnotetext{
a. tā měi-yī-tiān kàn nèi-běn shū kàn sān cì he every-CL-day read that-CL book read three times 'He reads that book three times every day.'

b. tã kàn nèi-běn shū kàn sān cì he read that-CL book read three times 'He read тнат воок three times (... and this book twice, etc.).'
} 
In (31a), měi-yì-tiān 'every-one-day' is a phrasal adjunct, which cannot morphologically fuse with the verb. (31b) provides a stronger piece of evidence that no extra material is available. In other words, these verb copying cases involving $\mathrm{D} / \mathrm{F}$ expressions seem to present a problem for the theory of copying that we have been exploring here.

However, as Ernst (1987) points out, there is another variant of D/F expressions, shown in (32), with the lower copy of the verb replaced by the verb yŏ ' 'have': 15
a. tā kàn nèi-běn shũ yŏu sān cì le
he read that-CL book have three times PRT
'He has read that book three times.'
b. wǒ rènshì tā yŏu shí-nián le
I know him have ten-years PRT
'I have known him for ten years.'

I propose that the two variants differ only in that the cases with verb copying involves a covert yŏ 'have' (indicated as HAVE), as represented in (33): 16

$$
\left[_ { \mathrm { vP } } \ldots \left[_{\mathrm{VP}}\right.\right. \text { that book read [HAve three times]] }
$$

To derive (29a) and (29b), the verb kàn 'read' copies and merges to the upper v. In the case of definite noun phrases (as represented in (33)), I suggest that fusion between the verb and the covert you is optional. If fusion takes place, the upper copy of the verb and the lower [verb plus you $u$ ] are distinct. Chain reduction does not apply and multiple realization of the verb becomes possible. If fusion does not take place, the copies are non-distinct, chain reduction applies, and only one copy (the upper one) remains.

With non-specific indefinites, which involve obligatory verb copying, I suggest that the second strategy of verb copying (involving Sideward Movement) is involved. This is due to the fact that non-specific indefinites cannot be merged in SpecVP, the affected object position (see Diesing 1992, Marantz 1993). This is further supported by the fact that such $\mathrm{V}$-O sequences always yield an activity reading. ${ }^{17}$

15. For lack of space, I do not discuss here the various readings that are possible with duration expressions. See Ernst 1987 and Li, 1987 for discussions of sentences such as (32).

16. Within the framework of lexical relational structures, the structure can be understood as saying that an event of reading has been realized 3 times (i.e., basically derived from an $e \rightarrow n$ relation).

17. There are thus two independent reasons why SpecVP is not used: (i) SpecVP is not available due to the ergative structure; and (ii) SpecVP cannot only host definite noun phrases. 


\subsection{Manner de-clauses}

Manner adverbial de-clauses present an interesting puzzle for the analysis of verb copying proposed here.' Consider again the data in (5) (repeated below as (34)):
a. *tā kàn zhè-běn xiăoshuō de hěn kuài
he read this-CL novel DE very fast
'He read this novel very fast.'
b. tã kàn zhè-běn xiăoshuō kàn de hěn kuài he read this-CL novel read DE very fast

(34a) shows that manner de-clauses differ from $\mathrm{D} / \mathrm{F}$ expressions in not allowing definite noun phrases to co-occur without reduplication; with manner de-clauses, there is no difference between definite and indefinite noun phrases (see (35)).
a. * tā kàn xiăoshuō de hěn kuài he read novel DE very fast 'He read this novel very fast.'
b. tā kàn xiăoshuō kàn de hěn kuài he read novel read DE very fast

Huang (1988) argues convincingly that the manner adverbial de-clauses should be treated as a type of secondary predication, with the adverbial clause being an inner adverbial. This gives us a basic VP structure for (35b) as:

$$
\text { [VP novel read [de very fast]] }
$$

Note that the object of the verb, novel does not begin within the secondary predicate, since the object noun phrase is not predicated by it. Assuming this structure, it is interesting to note that it is not possible to have (37) (in comparison with resultative de-clauses, as in (28)).
* tā kàn de (nèi-běn) xiăoshuō hěn kuài he read $D E$ that-CL novel very fast Intended: "He read the novel very fast.'

(37) can be derived if the manner-de clauses can also trigger ergativity shift. The fact that (37) is ungrammatical suggests that manner de-clauses do not trigger ergativity shift. This is not surprising since manner clauses are adverbials clauses, they cannot be interpreted as an inner argument of the verb. Further, though de in manner $d e$-clauses appear on surface to be the same as $d e$ in resultative $d e$-clauses, they are in fact different. This can be clearly seen in other dialects, such as Cantonese: $d e$ in the resultative clause is actually the verb dou 'arrive', while de in the manner adverbial clause is dak. 
I propose that $d e$ in manner-de clauses is always fused with the verb (indicated in the representation in (38)). ${ }^{18}$ The spelling out of both copies is allowed because the two copies are distinct. This derives the difference between manner de-clauses and $\mathrm{D} / \mathrm{F}$ expressions.

$$
\left[{ }_{\mathrm{vP}} \text { read }[\mathrm{vP} \text { that novel [read-DE] very fast }]\right]
$$

A question which arises concerns indefinite noun phrases occurring with manner declauses. I suggest that these can also be derived via Sideward Movement, assuming that indefinite noun phrases cannot be merged in SpecVP, as we mentioned above.

\subsection{Resultative compounds}

We turn now to verb copying in sentences with resultative compounds, which are comparable to resultative de-clauses in some ways but not identical to them. Consider now the basic data involving resultative compounds. ${ }^{19}$
a. tā qí-lèi-le (nèi-pī) mă
he ride-tired-PERF that-CL horse
(i) 'He rode the horse and the horse became tired.'
(ii) 'He got tired of riding the horse/horses.'
b. tã qí (nèi-pī) mă qí-lèi-le
he ride that-CL horse ride-tired-PERF
'He rode and got tired.' (Not: the horse is tired)
c. tā bă (nèi-pĩ) mă qí-lèi-le
he $\mathrm{BA}$ that-CL horse ride-tired-PERF
'He rode the horse and the horse became tired.'

As shown in (39a), when there is no verb copying, there is more than one reading available. ${ }^{20}$ As we see from the translation, both the "subject-result" and "object-result" readings are available. However, with verb copying, the "object-result" reading disappears. In this way, the interpretation with verb copying and the bă-variants differ. In the $b \breve{a}$-variant (with resultative compounds), as in the cases with resultative

18. De in manner-de clauses also has a neutral tone, suggesting that it is also a clitic/suffixal element.

19. Following traditional terminology, I use the term "compound" to describe these sentences; however, this does not imply that I believe that these verbal complexes are really derived by compounding. See Cheng 1997 for a mixed lexical-syntactic analysis, Huang 1992 for an alternative syntactic analysis and Li 1999, 2005 for a lexical analysis.

20. In fact, as $\mathrm{Li}$ (1999) points out, there are three readings available here. Since the number of readings in the non-copying cases is not important here, I illustrate only two. For a detailed discussion, see Li 1999, Cheng 1997 and Cheng and Huang 1994, as well as Sybesma 1999. 
de-clauses, only the "object-result" reading is available. In the verb copying case with resultative compounds, it is precisely this reading that is not available.

I follow Sybesma (1999) and assume a small clause analysis for the resultative compound sentences, as shown in (40) for (39a). (40) is a simplified structure of the VP. The perfective marker is assumed to be merged between V and SC. ${ }^{21}$

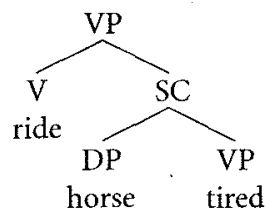

The structure can be interpreted as follows: there is a riding event such that the horse got tired. Within the Hale and Keyser (1993) framework, it is a dynamic event implicating a state (and thus a result). The subject of the matrix clause (merged in SpecVP) can thus be considered to be a causer of the dynamic event.

The structure in (40) derives the "object-result" reading. For the "subject-result" reading, the matrix subject is also the subject of the resultative small clause predicate, yielding a structure as in (41):

(41) [ ${ }_{\mathrm{VP}}$ ride $\left[\mathrm{SC}_{\mathrm{C}}\right.$ Zhangsan tired] $]$

This is comparable to the ergative structure proposed earlier for the subject-result reading in resultative de-clauses. In fact, both (42a) and (42b) are possible, showing that the "inner" argument becomes the matrix subject.

(42) a. Zhāngsān qí-lèi-le.

Zhangsan ride-tired-PERF

'Zhangsan is tired from riding (a horse).'

b. shŏupà kū shì-le

handkerchief cry wet-pERF

'The handkerchief is wet as a result of crying.'

\subsubsection{Verb copying with resultative compounds}

As we have seen in (39b), verb copying with resultative compounds is only possible if the resultative predicate is predicated of the matrix subject (see also Huang 1984). Compare the pair (39a-b) and $(43 a-b)$ with $(44 a-b)$ and $(45 a-b) .^{22}$

21. Given the structure $\left[_{V P}\right.$ ride $\left[\right.$ PrRF $\left[_{S C}\right.$ horse tired] $]$, tired subsequently moves up to the perfective marker. I think that there is no further movement to the matrix verb, though there is perhaps morpho-phonological merger of the matrix verb and the resultative complex (see Bobaljik 1995).

22. Some speakers consider (44b) to be good. I don't know whether this is a dialectal distinction or not. 
(43) a. tā chì-băo-le

he eat-full-pERF

'He is full.'

b. tā chī fàn chī-băo-le

he eat rice eat-full-PERF

'He got full by eating (rice).'

(44) a. tā xĭ-gānjíng-le yifú

he wash-clean-PERF clothes

'He washed the clothes and the clothes got cleaned.'

b. *tā xĩ yîfú xĩ gānjìng-le

he wash clothes wash clean-PERF

a. tā kū-shī-le shǒupà

he cry-wet-perf handkerchief

'He cried and handkerchief became wet.'

b. *tā kū shŏupà kū-shī-le

he cry handkerchief cry-wet-perF

c. tā bă shoupà kū-shī-le

he BA handkerchief cry-wet-PERF

'He cried the handkerchief wet.'

In the Examples (39b) and (43b), verb copying is allowed. But in (44b) and (45b), the ones having only the "object-result" reading, verb copying is not allowed.

Consider now the structures for the two result-readings:

(46) a. object-result: $\left[_{V P}\right.$ wash [SC clothes clean] $]$

b. subject-result: $\left[{ }_{V P}\right.$ eat $\left[\left[_{S C}\right.\right.$ he full $\left.]\right]$

Leaving the causer/agent aside, with "object-result", the theta-requirements of wash are satisfied, assuming that the argument within the $\mathrm{SC}$ is accessible to the matrix verb. ${ }^{23}$ On the other hand, in the case of the "subject-result", eat still has an object theta-feature to check.

We have shown that copying is triggered by Last Resort. Therefore, the thetarequirements of eat (i.e., the "subject-result" cases) can trigger verb copying, as in (43b). On the other hand, in the "object-result" cases, copying is not triggered by theta-requirements.

One question that remains concerns why the first strategy of verb copying is not available; why we do not have movement of the inner argument to matrix SpecVP position, as in the case of resultative de-clauses. Following Hoekstra and Mulder 1990, and Hoekstra 1992, I assume that a verb plus a resultative small clause

23. I assume that in de-clauses, the theta-features of the clause are not accesssible to the matrix verbs, while this is not true for small clauses. This is not so surprising since the de-clauses are full clauses. 
obligatorily yields an ergative structure (i.e., no structural object position). This means that SpecVP is not available with resultative compounds.

This also leads to $\mathrm{a}$ difference between resultative de-clauses and resultative compounds, since resultative de-clauses only optionally trigger ergativity shift (as discussed in Section 4).

Supportive evidence for this claim can be found from Chao-zhou dialects, as discussed in Matthews, Xu and Yip (2005). In Jieyang (one of the Chao-Zhou dialects), the marker $k^{\prime} e$ ? is obligatorily used to mark passive and ergatives: ${ }^{24}$
a. ua tiam $\mathrm{k}^{\prime} \mathrm{e}{ }^{*}$ (i) me
I , always PAss 3 sG scold
'I keep being scolded by him.'
b. kai nou-kiã k'e? i pua? lo? k'u CL child Pass 3sg fall down RVC 'The child fell over.'

When an unergative verb such as tsau 'run' is followed by a resultative verb, as in (48), the marker $k$ ' $e$ ? also appears obligatorily. See also the examples in (49), where the verb $i$, 'sleep' becomes ergative when the resultative verb is added (49b).

(48) sã kai ts'a? k'e? i tsau k'ur three CL thief pass 3sg run RVC 'Three thieves escaped.'

(49) a. ua t'õi tiangsi au tsu k'ur $\tilde{1}$, I watch TV after then go sleep 'I went to sleep after watching TV.'

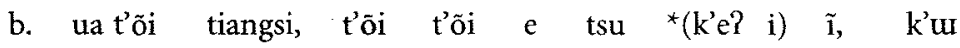
I watch television watch watch ASP then PASS 3sG sleep RVC 'I fell asleep while watching television.'

The contrast between resultative de-clauses and resultative compounds is also reflected in the Jieyang dialect. In Jieyang, kau is the equivalent of $d e$. We see in the resultative kau-clauses in Jieyang in $(50 \mathrm{a}, \mathrm{b})$, the marker $k^{\prime} e$ ? is optional. ${ }^{25}$
a. ua k'e? i tsia? kau kai tou t'iã, si
I PASS 3sG eat until CL stomach hurt Rve 'I ate until my stomach hurt.'
b. ua tsia? kau kai tou t'iã, si
I eat until CL stomach hurt RvC
'I ate until my stomach hurt.'

\footnotetext{
24. The resultative verb $k$ ' $u$ means literally 'go'.

25. I thank Stephen Matthew for providing the data in (50).
} 
From the Jieyang Chao-Zhou dialect we have seen confirming evidence that a clausal resultative yields optional ergativity shift while resultative compound verbs yield obligatory ergativity shift. This difference in ergativity shift leads to the difference we have seen in the availability of the verb copying strategies.

\subsubsection{Extra argument}

The cases of verb copying involving resultative compounds concern the "subjectresult" cases. There are however other cases which do not have a straightforward "subject-result" reading but they do allow copying. These are also cases which provide supporting evidence for the Last Resort requirement of copying and Sideward Movement. These cases involve an "extra" argument. Consider first the two sentences in (51).
a. tā kàn shū kàn-lèi-le yănjīng He read book read-tired-perf eye 'He tired his eyes by book-reading.'
a. tāà tī qiú tî-pò-le qiú-xié he kick ball kick-broken-PERF sport-shoe 'He broke his sport-shoes by ball-kicking.'

The VP structures of these two sentences before verb copying are:
a. $\left[\mathrm{Vp}_{\mathrm{VP}}\right.$ read [ $\mathrm{SC}_{\mathrm{SC}}$ eye tired $\left.\mathrm{]}\right]$
b. [ ${ }_{\mathrm{VP}}$ kick $[\mathrm{SC}$ sport-shoe broken $\left.]\right]$

In both examples, the argument inside the resultative small clause is not an internal or extenal argument of the verb. In other words, the.internal theta-feature of these verbs is still available. Hence, verb copying can be triggered (and Sideward Move with the object noun phrase), and we derive the sentences in (51). Note that the object of the verb in these cases differ from the subject of the result predicate. This falls out very well given the current analysis, as these sentences still involve resultative compounds and thus obligatory ergativity shift is involved.

It should be also noted that $(51 \mathrm{a}, \mathrm{b})$ do not have a $b \vec{a}$-variant, as the ungrammatical $(53 a, b)$ show. This provides further evidence for the claim that $b a$ does not introduce its own argument; the noun phrase associated with $b \breve{a}$ must be first merged in another position. ${ }^{26}$

26. The subject of the resultative predicate can raise to SpecVP position in the matrix to create a $b a ̆$-sentence:

(i) a. tā bă yănjīng kàn-lèi-le

he $B A$ eye read-tired-PERF

'He made his eyes tired by reading.' 

a. *tā bă shū kàn-lèi-le yănjīng
he BA book read-tired-PERF eye
b. *tā bă qứú, tî-pò-le . qiú-xié
he BA ball kick-broken-PERF sport-shoe

In addition, $(54 a, b)$ show that the copy of the verb can take a dummy object, if the verb is an unergative verb (see Cheng and Sybesma 1998 regarding dummy objects). Crucially, the copied verb does not take a derived object, as shown in (54b).
a. tā păo-lèi-le tŭ
he run-tired-perf leg
b. * tā păo tŭi păo-lèi-le
he run leg run-tired-perF
c. tã păo-bù păo-lèi-le tŭ
he run-step run-tired-pERF leg
'He ran and as a result his legs got tired.'

Lastly, I would like to turn back to the Last Resort requirement, which should not allow optionality. But in almost all of the verb copying cases with resultative compounds, there is also a no-copy variant, i.e., no verb copying at all:
a. tā qí-lèi-le
he ride-tired-PERF
'He is tired because of (horse-back) riding.'
b. tā chī-băo-le
he eat-full-PERF
'He is full.'
c. tā kàn-lèi-le yănjīng
he read-tired-PERF eye
'His eyes are tired from reading.'
d. tā tì-pò-le qíu-xié
he kick-broken-PERF sport-shoe
'His sport-shoes are broken because of soccer playing.' ${ }^{37}$
e. tã păo-lèi-le tuí
he run-tired-PERF leg
'His legs are tired because of running.'
b. tã bă qiú-xié tì-pò-le
he BA sport-shoe kick-broken-pERF
'He made his sport-shoes torn by kicking.'

This suggests bă can license an extra SpecVP despite of the ergativity shift in resultative compounds.

27. Speakers disagree as to whether or not the kicking here can be kicking other things than a soccer ball. 
If Copy is triggered by Last Resort, and we have seen that the verb copying cases in Mandarin verb copying is triggered by the theta-requirement of the verb, then the lack of verb copying in (55) become problematic.

The optionality that I am pointing out now has to do with the satisfaction of the theta-requirement of the verb. Crucially, if the verb is ergative, can it still have the theta-feature to be checked? I speculate here that the ergativity has to do with the structure, but it does not affect the theta-features (which may be suppressed and hence optional).

\section{Conclusion}

I have shown that we can treat verb copying in different types of constructions in Mandarin Chinese under one umbrella. All verb copying involves either standard movement of a noun phrase plus verb movement, or Sideward Movement of the verb. In all cases, due to a modified structure in the lower copy, both copies are allowed to be pronounced, without violating the LCA.

If the analysis of verb copying proposed here is on the right track, we have further evidence for Last Resort trigger of copying: both for copying of noun phrases (i.e., DP movement) and for copying of verbs (i.e., $\mathrm{V}$ movement). In both cases, the theta-requirement of the verb is the sole trigger for the copying.

Given the analysis of verb copying, structural analyses of the various complemental and adverbial expressions are suggested, mostly making certain choices from previous analyses. I have further shown that ergativity is associated with resultatives, either optionally or obligatorily. The remaining question rests upon how theta-features are affected by modified argument structure which are imposed in syntax.

\section{References}

Bobaljik, Jonathan David. 1995. Morphosyntax: The syntax of verbal inflection. PhD Dissertation, MIT.

Cheng, Lisa L.-S. 1997. Resultative compounds and lexical relational structures. Symposium Series of the Institute of History and Philology, Academia Sinica 2: 167-197.

Cheng, Lisa L.-S. \& Huang, C.-T. James. 1994. On the argument structure of resultative compounds. In A Festschrift for William S.-Y. Wang, Matthew Chen \& Ovid Tzeng (eds), p. 187-221. Taipei: Pyramid Press.

Cheng, Lisa L.-S. Sybesma, Rint. 1998. On dummy objects and the transitivity of run. In Linguistics in the Netherlands 15, ed. Renée van Bezooijen \& Rene Kager, 81-93. Amsterdam: John Benjamins.

Diesing, Molly. 1992. Indefinites. Cambridge MA: The MIT Press. 
Ernst, Tom. 1987. Duration adverbials and Chinese phrase structure. Journal of the Chinese Language Teachers Association 12:1-11.

Gouguet, Jules. 2004. Verb copying and the linearization of event structure in Mandarin. Ms. Universite de Paris 7.

Hale, Ken \& Keyser, S. Jay. 1993. On argument structure and the lexical expression of syntactic relations. In The view from building 20: Essays in linguistics in honor of Sylvain Bromberger, Kenneth Hale \& Samuel Jay Keyser (eds). Cambridge MA: The MIT Press.

Halle, Morris \& Marantz, Alec. 1993. Distributed morphology and the pieces of inflection. In The view from building 20: Essays in linguistics in honor of Sylvain Bromberger, Kenneth Hale and Samuel Jay Keyser (eds), 111-176. Cambridge MA: The MIT Press.

Hoekstra, Teun \& Mulder, René. 1990. Unergatives as copular verbs; locational and existential predication. The Linguistic Review 7: 1-79.

Hoekstra, Teun. 1992. Aspect and theta-theory. In Thematic structure: Its role in grammar, I.M. Roca (ed.), 145-174. Berlin: Foris.

Hornstein, Norbert. 1999. Movement and control. Linguistic Inquiry 30: 69-96.

Hornstein, Norbert \& Nunes, Jairo. 2002. On asymmetries between parasitic gap and across-the board constructions. Syntax 5: 26-54.

Huang, C.-T. James. 1982. Logical relations in Chinese and the theory of grammar. PhD Dissertation, MIT.

Huang, C.-T. James. 1984. Phrase structure, lexical integrity, and Chinese compounds. Journal of Chinese teacher's association 19: 53-78.

Huang, C.-T. James. 1988. Woŏ paăo de kuài and Chinese phrase structure. Language 64: 274311.

Huang, C.-T. James. 1992. Complex predicates in control. In Control and Grammar, Richard Larson, Sabine Iatridou \& Utpal Lahiri (eds), 109-147. Dordrecht: Kluwer.

Kayne, Richard. 1994. The antisymmetry of syntax. Cambridge MA: The MIT Press.

Li, Audrey Yen-hui. 1987. Duration phrases: Distributions and interpretations. Journal of the Chinese Language Teachers Association 12: 27-65.

Li, Yafei. 1999. Cross-componential causativity. Natural Language and Linguistic Theory 17: $445-497$.

Li, Yafei. 2005. $X^{0}:$ A theory of the morphology-syntax interface. Cambridge MA: The MIT Press.

Marantz, Alec. 1993. Implications of asymmetries in double object constructions. In Theoretical aspects of Bantu grammar 1, Sam A. Mchombo (ed.), 113-150. Stanford CA: CSLI.

Matthews, Stephen, $\mathrm{Xu}$, Huiling \& Yip, Virginia. 2005. Passive and unaccusative in the Jieyang dialect of Chaozhou. Journal of East Asian Linguistics 14: 267-298.

Nunes, Jairo. 2001. Sideward movement. Linguistic Inquiry 31(2): 303-344.

Nunes, Jairo. 2004. Linearization of chains and sideward movement. Cambridge MA: The MIT Press.

Paul, Waltraud. 2002. Proxy categories in phrase structure theory and the Chinese VP. Cahiers de Linguistique-Asie Orientale 31: 137-174.

Sybesma, Rint P.E. 1999. The Mandarin VP. Dordrecht: Kluwer. 